\title{
Method of Payment and Target Status: Announcement Returns to Acquiring Firms in the Malaysian Market
}

\author{
Mansor Isa \\ Faculty of Business and Accountancy, University of Malaya \\ Lembah Pantai, 50603 Kuala Lumpur, Malaysia \\ Tel: 60-3-7967-3800Ｅ-mail: mansor@um.edu.my \\ Siew-Peng Lee (Corresponding author) \\ Faculty of Accountancy and Management \\ University of Tunku Abdul Rahman, Lot PT 21144, Jalan Sungai Long \\ Bandar Sungai Long, 43000 Kajang, Malaysia \\ Tel: 60-3-9019-4722_E-mail: leesp@utar.edu.my
}

Received: November 10, $2010 \quad$ Accepted: December 21, $2010 \quad$ doi:10.5539/ijef.v3n3p177

\begin{abstract}
This paper examines the impact of acquisition announcements on the acquirer's returns in the Malaysian market for the period from 2000 to 2005. Using the market model with infrequent trading adjustments, our results reveal that acquiring firms obtain positive abnormal returns on the announcement day. When acquisitions are analyzed based on target firm status, we find that public acquisitions provide higher abnormal returns to the acquiring firms than private acquisitions. In terms of method of payment, the evidence suggests that cash acquisitions generate positive abnormal returns for the acquiring firms regardless of the target firm status. Finally, the size of the acquired asset value relative to the acquiring firms is positively associated with the acquiring firm's abnormal returns.
\end{abstract}

Keywords: Acquisition, Acquirer's return, Method of payment, Target status

\section{Introduction}

Most studies on mergers and acquisitions seem to have agreed that target firms receive a significantly positive abnormal return around the announcement period, while acquiring firms reveal mixed findings. Certain studies reported that acquiring firms experience positive abnormal returns, while others found negative abnormal returns and some even found non-significant abnormal returns. In a comprehensive paper, Jensen and Ruback (1983) review 13 empirical studies on mergers and acquisitions that analyze abnormal returns around the mergers and takeover announcements. Their general conclusion is that target firms gain while acquiring firms do not lose.

One important element in corporate acquisition is the method of payment used to settle the transaction. The most commonly used methods of payment are full cash, full share-exchange or a combination of both. Previous studies find that the methods of payment have an impact on the announcement returns. Fuller, Netter and Stegemoller (2002) support the early findings that acquiring firms with cash offers show higher returns than those with share offers. However, the evidence on the impact of share offer acquisitions is inconclusive, some studies (for example, Moeller, Schlingemann and Stulz (2004) and Ismail (2008)) find significant gains while others (for example, Andrade, Mitchell and Stafford (2001) and Fuller, Netter and Stegemoller (2002)) find significant loss.

Another issue relating to acquisition announcement return is the status of the target, that is, whether the targets are private and unlisted firms or public listed firms. There is very little research done on the returns of acquiring firms in relation to target status. Two of the latest studies on this topic were those of Fuller, Netter and Stegemoller (2002) for the U.S. market, and Draper and Paudyal (2006) for the U.K. market; both studies find that acquirers gain when acquiring a private target and lose when acquiring a public target.

We note that most of the previous studies on acquisition were conducted in the developed markets, particularly the U.S. and U.K. markets, and very little research has been done on developing markets. Hence, it begs the question of whether their findings are equally relevant to a developing market. In this study, we focus on the returns to the acquiring firms during acquisition announcement in the Malaysian stock market for the period 2000 to 2005 . We first examine the market reaction to acquiring firm returns in acquisition around the announcement date. We then 
analyze the market reaction in relation to target status and methods of payment. We hope that by studying this event in a developing country, such as Malaysia, we would be able to assess whether related finance theories that have been found relevant in developed markets are equally applicable in a developing market.

The rest of the paper is organized as follows. The next section reviews the relevant literature, and Section 3 describes the data and methodology used in the study. Section 4 discusses the results and Section 5 presents the conclusion.

\section{Literature Review}

\subsection{Performance of Acquiring Firms}

Empirical evidence in the U.S. largely supports that acquisitions create value for shareholders, although some evidence to the contrary exists. Value creation evidence is quite clear for target firm shareholders, but less certain for acquiring firm shareholders. Some U.S. studies report that acquiring firms earn a statistically significant positive abnormal return. For example, Asquith, Burner and Mullins (1983) and Asquith and Kim (1982) find that acquiring firms earn significant positive abnormal returns of $0.2 \%$ to $1 \%$ on the announcement day. Later studies, such as Fuller, Netter and Stegemoller (2002), Moeller, Schlingemann and Stulz (2004), Draper and Paudyal (2006) and Ismail (2008) also find similar evidence. In contrast, there are studies that report negative returns for the acquiring firms, for example, Amihud, Lev and Travlos (1990), Healy, Palepu and Ruback (1992), and Moeller et al. (2005). Furthermore, there are studies, for example, Bradley, Desai and Kim (1983), Draper and Paudyal (1999), Faccio, McConnell and Stolin (2006) that find that abnormal returns to acquiring firms are not significantly different from zero. In developing markets, Koh and Lee (1988), and Cheung and Shum (1993) find no significant abnormal return to the acquiring firms in the Singapore and Hong Kong markets, respectively. In fact, Cheung and Sum (1993) document that acquiring firms suffer a significant $-16.09 \%$ abnormal returns over the 61-day event window in their study. In Malaysia, Isa and Lim (1993), Mat-Nor (1993) and Isa (1994) report that around the announcement days both the acquiring and target firms earn positive abnormal returns.

\subsection{Method of Payment}

Previous studies (e.g., Travlos and Papaioannou, 1991; Draper and Paudyal, 1999; and Faccio and Masulis, 2005) indicate that different methods of payment in acquisition yield different impacts on acquiring firm's share prices around the announcement period. There seems to be a general consensus among the empirical studies that the acquiring firms have higher excess returns in cash acquisitions compared to in share-exchange acquisitions.

For acquiring firms, Martynova and Renneboog (2008) and Ismail (2008) find that all-cash acquisitions generate higher returns to acquirers than share-exchange acquisitions. The explanation is that the announcement of a cash acquisition signals to the market that acquiring managers believe that their firm's shares are underpriced. However, the evidence on the effect of share-exchange acquisitions on acquiring firms is mixed; Travlos (1987) reports significantly negative abnormal returns of $1.47 \%$ over the period (day -1 to 0 ), while Wansley, Lane and Yang (1987) report that acquirers earn insignificant negative abnormal returns. Moeller, Schlingemann and Stulz (2004) report significant positive abnormal returns over the three-day announcement period (day -1 to day 1) in both cash and share acquisitions. In the Malaysian market, Isa (1994) reports that acquiring firms in cash acquisitions earn a positive return of $0.12 \%$ and share acquisitions earn a negative return of $0.65 \%$ over the period of day -1 to day 0 .

The signaling model of Leland and Pyle (1977) and Myers and Majluf (1984) suggests that due to information asymmetry, managers prefer cash offers if they believe that the acquiring firm's share is undervalued. As such, the method of payment acts as a signaling device about the acquiring firm's stock value; investors interpret cash offers as good news and share offers as bad news. Consequently, proposals of cash offers in acquisition are expected to have a positive impact, whereas the share offers are expected to have a negative impact on the acquiring firm's share price. This suggests that cash-offer acquisitions should gain more than share-offer acquisitions.

\subsection{Target Firm Status}

In an acquisition, a listed firm may acquire another public listed company or a private and unlisted company. There are several basic differences in the valuation and pricing of a private vis-à-vis a public firm. Normally, private firms are closely held by a limited number of shareholders; often times they are family owned and contain a high proportion of owner-managers. Their shares are not publicly traded and; therefore, valuation can be difficult. Consequently, acquiring a private company may be subject to a different expectation from the target shareholders. The works of Chang (1998), Ang and Kohers (2001), Fuller et al. (2002), and Draper and Paudyal (2006) report that acquirers of private targets experience positive returns while acquirers of public targets suffer losses in acquisitions. We discuss below several hypotheses offered by Chang (1998), and Draper and Paudyal (2006) to explain the reasons for the differences in returns to acquirers in relation to the status of the targets. 


\subsubsection{The managerial motive hypothesis}

The managerial hypothesis says that acquirers are motivated by "private benefits" such as increased prestige when acquiring another public company. Hence, they are willing to "pay extra" so long as the acquisition is successful. This hypothesis is suggested by Draper and Paudyal (2006), and Agrawal and Samwick (2003). However, when acquiring a smaller and less known private firm, the private motive no longer applies, instead acquirers are more motivated by the potential synergies from the acquisition and a desire to maximize their shareholders' wealth. This hypothesis predicts that acquirers tend to overpay for public targets and not overpay the private targets. Thus, announcements of public target acquisitions should bring less benefit to the shareholders of the acquiring firms compared to the announcement of private target acquisitions.

\subsubsection{The liquidity hypothesis}

If the acquisition market is competitive, the acquisition itself will be a zero net present value transaction, and the acquiring firm should have no abnormal returns around the announcement date (Chang, 1998). However, Draper and Paudyal (2006) argue that this outcome depends on the availability of information to generate competition among potential acquirers. Information on a public target is normally readily available for the purpose of valuation and shares are publicly traded. Assuming an efficient market, share prices of a public target are reasonable estimates of firm value, whereas a private firm is not publicly traded and information is scarce and hard to obtain. Because of the illiquid market for private targets and the lack of competition therein, acquiring firms have greater bargaining power in negotiation. This suggests that acquirers of private targets should gain more than acquirers of public targets.

\subsubsection{The bargaining power hypothesis}

Normally, private firms are closely held by a limited number of shareholders; hence, managers of private firms are more concerned to ensure a positive impact on firm value in acquisition negotiation. Draper and Paudyal (2006) suggest that closely controlled firms may have significant bargaining strength, which allows the owners to receive a better price for their firm. Therefore, acquirers of a private target may have to agree to a higher price, thereby reducing potential benefits to their shareholders. This argument contradicts previous arguments in predicting lesser gains to acquirers of a private target compared to acquiring a public target. Additionally, if it is a share-exchange offer, target shareholders may end up as a significant block holder of the acquiring firm in the post-acquisition period. Consequently, the target's shareholders may play an effective monitoring role in ensuring the post-acquisition activities are in the shareholders interest. This hypothesis predicts greater returns to acquirers of a private target compared to acquirers of a public target.

\section{Methodology}

\subsection{Data}

Our sample covers all non-financial firms that were listed on the Malaysian stock exchange from 1 January 2000 through 31 December 2004. The information on corporate acquisition and the announcement date were obtained from different sources. Prior to July 2003, the source of data was the "Record of Issues" section contained in the monthly publication of the exchange, called the Investor Digest. The data was hand-collected from this publication. Acquisition data for July 2003 onwards was obtained from the exchange website. Each announcement date obtained from these sources was crosschecked with the Business Times daily newspaper. The event date taken is effectively the first announcement that appeared in the press on the acquisition.

Acquisition of companies may be of different amounts and sizes, ranging from a small fraction of the target to $100 \%$ take over. Asquith, Burner and Mullins (1983), and Rahman and Limmack (2004) suggested that if the investment amount in the target is small relative to the value of the acquiring firm, the change in value from the acquisition may not cause much change in the acquiring firm's share price. To be included in this study the acquisition size must be more than $33 \%$ of the voting rights of the target firm with a purchase value no less than RM10 million. The initial sample consists of 188 observations. Screening for the availability of information on firm share price, acquirer's size and acquisition value reduces the sample to 139 observations for acquiring firms. Share prices and index values were obtained from the Bloomberg database.

\subsection{Method of Analysis}

This study uses standard event study methodology to examine the market reaction to an acquisition announcement. The analysis starts with the estimation of the market model parameters for firm $i$ on day $t$ in the estimation periods, before and after the event:

$$
R_{i, t}=\alpha_{i}+\beta_{i} R_{m, t}+\varepsilon_{i, t}
$$

where, 
$R_{i, t}=$ the daily stock return of firm $i$ on day $t$,

$R_{m, t}=$ the daily market return (Kuala Lumpur Composite Index) on day $t$,

$\alpha_{i}=$ the intercept measuring the mean return over the period that is not explained by the market,

$\beta_{i} \quad=$ the slope coefficient measuring the sensitivity of firm's stock $i$ to the market,

$\varepsilon_{i, t}=$ is an uncorrelated error term with mean zero and constant variance.

To account for thin trading in the Malaysian market, we use the Sholes-Williams (1977) method to adjust the OLS parameters of $\hat{\alpha}_{i}$ and $\hat{\beta}_{i}$. These parameters are estimated separately before and after the announcement. Before the announcement, the estimation period is for 100 days, from day -130 to day -31 relative to the announcement day (day 0). The estimation period after the announcement is from day 31 to day 130. These estimates obtained from the pre-event estimation period are used to obtain the pre-announcement (days -30 to -1) abnormal returns and those obtained in the post-event estimation period are used to obtain the abnormal return for the announcement and post-announcement days (days 0 to 30 ). The abnormal returns are calculated as follows:

$$
A R_{i, t}=R_{i, t}-\hat{R}_{i, t}
$$

where,

$$
\begin{aligned}
& A R_{i, t}=\text { abnormal returns for firm } i \text { on day } t, \\
& R_{i, t}=\text { actual returns for stock } i \text { on day } t, \\
& \hat{R} \quad=\text { expected return calculated from the market following model equation: } \\
& \qquad \hat{R}_{i, t}=\hat{\alpha}_{i}+\hat{\beta}_{i} R_{m, t}
\end{aligned}
$$

where $\hat{\alpha}_{i}$ and $\hat{\beta}_{i}$ are the Sholes-Williams estimates of the OLS parameters. For each day $t$ within the event study, the cross-section average abnormal return $\left(\overline{A R}_{t}\right)$ is calculated as follows:

$$
\overline{A R}_{t}=\frac{1}{N} \sum_{i=\mathrm{e}}^{N} A R_{i, t}
$$

where $\overline{A R}_{t}$ is average abnormal ${ }^{i}$ return for day $t$, and $N$ is the number of stocks in the portfolio. The cumulative abnormal return $\left(C A R_{t}\right)$ is obtained by accumulating the daily average abnormal returns from the beginning of the event period.

$$
\overline{\operatorname{CAR}}_{T_{1}, T_{2}}=\sum^{T_{2}} \overline{A R}
$$

The $\overline{\operatorname{CAR}}_{T_{1}, T_{2}}$ reveals the average ${ }^{T}$ total effect of an acquisition announcement over the specific period. To test for the significance of abnormal returns, $A R_{i, t}$ is divided by its estimated standard deviation, $S\left(A R_{i, t}\right)$ to yield a standardized abnormal return, $A R^{\prime}{ }_{i, t}$.

$$
A R_{i, t}^{\prime}=\frac{A R_{i, t}}{S\left(A R_{i, t}\right)}
$$

where,

$$
\begin{aligned}
& S\left(A R_{i, t}\right)=\sqrt{\left(\frac{1}{100-1}\right) \sum_{T_{1}}^{T_{2}}\left(A R_{i, t}-A R_{i}^{*}\right)^{2}} \text { and } \\
& A R_{i}^{*}=\frac{1}{100} \sum_{T_{1}}^{T_{2}} A R_{i, t}
\end{aligned}
$$

where $T_{1}$ and $T_{2}$ are the beginning and ending days of the estimation periods. The test statistic for any given day is given by:

$$
T_{t}=\left(\sum_{i=1}^{N_{i}} A R_{i, t}^{i}\right) *\left(N_{t}\right)^{-1 / 2}
$$

\subsection{Sample Description}

Of the 139 acquisition announcements, 32 (23\%) are for acquiring public (listed) targets and 107 (77\%) are for acquiring private (unlisted) firms. Tables 1 (a) and (b) report the distribution of our data by year, the yearly mean and median of the acquirers and the target size (value of purchase) over the study period. The size of the acquiring firms equals the share price one month prior to the announcement multiplied by the number of shares issued. While for the target, the size equals the value of the deal when announced.

The table shows that not only are public targets larger than private targets, but also the acquirers of public targets are larger than acquirers of private targets. There is also a great variation in the mean size of acquirers from year to year, 
particularly for public acquisitions. Another point worth noting is that the private targets are indeed very small relative to their acquirers with a mean relative size of $8.0 \%$, while the relative size for public targets is $31.8 \%$.

Insert Table 1(a) and 1(b)

\section{Empirical Results}

\subsection{Returns to Acquiring Firms}

Table 2(a) presents our analysis of abnormal returns around the announcement day to the acquiring firms. The table shows the daily average abnormal returns (AR) and the respective $t$-statistics, and also the cumulative abnormal returns (CAR) that are accumulated beginning from day -30 to day -30 . Table 2(a) shows that significantly positive abnormal returns exist for day 0 and day 1 for the acquiring firms. Returns on other days are practically non-significant. The behavior of the cumulative abnormal returns (CAR) is shown in Figure 1. The Figure shows that the CAR takes a slight upward trend during the event window with a small hump that lasts for a few days beginning from day 0 . These results clearly show the existence of a significant positive impact of the announcement to the acquiring firms.

Table 2(b) presents the analysis on the cumulative abnormal returns (CARs) and the corresponding $t$-statistic for various sub-windows within the event window. Since there may be uncertainty as to the exact date that the announcement information becomes public, it is safer to take 3 days around day 0 , that is day -1 to day 1 as the announcement period. We note first that CAR for the announcement days (day -1 to 1 ) is $1.48 \%$, significant at the $1 \%$ level. Second, for the entire event window, day -30 to day 30 , the acquiring firm's CAR of $2.64 \%$ is insignificant at the $10 \%$ level. The pre- and post-announcement periods CAR are also insignificant.

Past evidence on the performance of the acquiring firms are mixed; the majority of the studies show non-positive CAR, while some studies show small positive CAR. In their widely cited paper, Jensen and Ruback (1983) conclude that acquiring firms do not lose. In a more recent paper, Martynova and Renneboog (2008) review the academic literature on the mergers and acquisitions studies and find that acquiring firms earn announcement abnormal returns that are "statistically indistinguishable from zero". Our results, which show that acquiring firm overall returns are not significant over the event period, are consistent with most of the previous literature, for example Bradley, Desai and Kim (1983), Moelller, Stegemoller and Stulz (2004), and Draper and Pudyal (2006).

Insert Table 2(a)

Insert Figure 1

Insert Table 2(b)

\subsection{Acquiring Firm Returns and Target Status}

Table 3 shows abnormal return analysis for acquiring firms based on the target status. The table shows that the purchase of either private or public targets would yield significant abnormal returns to the acquiring firms. The announcement period CAR is $1.24 \%$ (significant at the $1 \%$ level) and $2.20 \%$ (significant at the $5 \%$ level) for acquiring private targets and public targets, respectively. In addition, we note that the announcement impact for public acquisition is greater than for private acquisition. For the entire event window (day -30 to day 30), the public acquisition CAR is $4.53 \%$ compared to the private acquisition CAR of $0.50 \%$, giving a difference of $4.03 \%$, which is significant at the $10 \%$ level (significance test not shown). On the whole, our results indicate that public acquisitions generate greater abnormal returns than private acquisitions to the acquiring firms.

\section{Insert Table 3}

Our results in this section contradict the findings of most of the previous studies that show that private acquisitions generate greater abnormal returns than public acquisitions. These include the studies by Chang (1998), Fuller et al. (2002), Conn et al. (2005) and Faccio et al. (2006). For example, Fuller et al. (2002) find that acquiring public targets yield an abnormal return of $0.57 \%$ (insignificant) for the acquiring firms during the event period of days -2 to 2 , while acquiring private targets yield an abnormal return of $1.90 \%$ (significant at the $5 \%$ level). Draper and Paudyal (2006) find that acquirers for public target experience a significant loss of $0.41 \%$ (significant at the $5 \%$ level) while acquirers for private target experience a significant gain of $0.81 \%$ (significant at the $5 \%$ level) around the event period (day -1 to 1 ).

Two explanations have been proposed by Chang (1998), and Draper and Paudyal (2006) to explain why private acquisitions should generate greater returns than public acquisitions. One is the managerial motive and the other is the liquidity hypothesis. The managerial motive states that acquisitions are motivated by shareholder wealth maximization. In other words, acquiring a private target is considered as a positive net present value investment for the acquiring firm; hence, an upward movement in share prices is expected. However, when acquiring a public 
target, managers of acquiring firms may be more influenced by "private benefits" rather than maximizing shareholder value. Hence, public acquisitions tend to generate less or no abnormal returns, or even negative abnormal returns.

The liquidity hypothesis is based on the fact that a public target has liquidity in the sense that the shares are publicly traded on an exchange and prices are determined by the market. Conversely, a private target does not have such liquidity and the deal value is arrived at through private negotiation. The liquidity hypothesis says that acquiring firms pay a liquidity premium to the public listed target and no liquidity premium to the private targets. Hence, acquisition benefits would be less when acquiring a public firm compared to acquiring a private firm.

Our results are not consistent with either of these hypotheses. However, that does not mean that the hypothesis is invalid in Malaysia. Both the managerial motive and liquidity hypotheses may be considered as universal behaviors and should be applicable in all markets. In addition, there may be other forces that are present in our data that overcome the value maximization and liquidity motives. One such possibility is the bargaining power hypothesis. This hypothesis states that the closely held nature of the private target leads to greater bargaining power of the target's management, which ends up with the acquiring firm having to pay more than when acquiring a similar public target.

\subsection{Interaction between Target Status and Method of Payment}

Acquiring firms may make an offer to buy shares of target firms either in the form of cash settlement or share-exchange settlement or a combination of both. Previous studies indicate an overwhelming preference for cash. We address this issue in our study by dividing the sample according to the method of payment. The majority of acquisitions are full cash offers (99 out of 139 cases or $71 \%$ ), while 26 cases $(19 \%)$ are full share offers and the remaining 14 cases $(10 \%)$ are mixed offers. Following the work of Draper and Paudyal (2006), this study only looks at full cash and share offers.

Table 4 shows abnormal return analysis in relation to the method of payment and target status. The last two columns of the table show that cash-settlement offers are clearly preferred by shareholders to share-settlement offers. The table shows that there is a positive abnormal return of $1.43 \%$ (significant at $1 \%$ level) on the announcement days of -1 to 1 , for cash settlement and an insignificant abnormal return for share settlement. The overall gain for the entire window also shows that the CAR for the cash offer $(2.85 \%)$ is greater than for the share offer $(-0.52 \%)$.

\section{Insert Table 4}

The signaling hypothesis of Myers and Majluf (1984) stipulates that the market believes that acquiring managers use cash payments when their shares are undervalued (hence, positive market reaction) and use share payment when their shares are overvalued (hence, negative market reaction). The acquirer's shareholders preference for cash-offers, as shown by our evidence, is consistent with the signaling theory.

In terms of target status, our findings suggest that public acquisitions generate greater returns to acquiring firms than private acquisitions, for both methods of payment. For cash settlement, the CARs for the announcement period are $1.02 \%$ (significant at the 5\% level) and $2.70 \%$ (significant at the $5 \%$ level) for private and public acquisitions, respectively. It is also observed that for all the sub-windows in the cash settlement subsample, the public CAR is greater than the private CAR. For share-offer settlement, we find the results to be less deterministic compared to the cash-offer settlement, however, there is a tendency for the public acquisitions to have a greater abnormal return compared to private acquisitions. Comparing methods of payment for the different target status, we find that cash settlement is clearly preferred to share settlement for both public and private targets.

Our results are not consistent with the corporate monitoring hypothesis proposed by Chang (1998), and Fuller et al. (2002), which says that private acquisition with share offers should have greater returns than cash offers because the private targets are usually owned by a family or a limited number of partners and, thus, could effectively monitor post-acquisition activity. Our results are consistent with Da Silva Rosa et al. (2004) who find that share settlement for private acquisitions is not associated with higher abnormal returns to acquirers. We rationalize our results by the fact that the size of the private targets is very small relative to the size of the acquiring companies. Hence, the target shareholders would not become a significant block holder that could effectively monitor post-acquisition activity.

\subsection{Relative Size of Acquisition}

Eckbo, Maksimovic and Williams (1990) mentioned that the relative size of the target to acquiring firms may be a factor in determining the size of abnormal returns to the acquiring firms. Acquiring a target that is relatively very small compared to the acquirer's size would result in little value added to the acquiring firm, which may not be statistically significant. Therefore, it makes sense to expect the size of the acquisition to be related to the amount of benefits the acquirer will obtain. To explore this issue, we calculate the relative size of the acquisition by dividing 
the asset purchase value by the market value of the acquiring firm. We then rank the sample by the relative size and divide it into two equal sub-samples of high and low relative sizes, respectively. The acquirer market value is calculated using the market price one month prior to the announcement multiplied by the number of shares outstanding. The target value for acquisition is taken as the deal value as announced.

Table 5(a) reports the abnormal returns analysis for the acquiring firms based on the relative size for the private acquisition. The results show that large acquisitions tend to yield greater abnormal returns to acquirers compared to small acquisitions. This is true for all sub-windows. Similar observations may be made for the public acquisitions as shown in Table 5 (b). These results are consistent with those of Asquith, Burner and Mullins (1983), Jensen and Ruback (1983), and Fuller et al. (2002) who find that acquirer abnormal returns increase with the relative size of acquisition.

Insert Table 5(a) and 5(b)

Comparing the private versus public acquisitions by relative size (i.e. Table 5(a) versus Table 5(b)) we find that the public acquisitions yield greater returns than the private acquisitions for all sub-windows and for both size categories. Because the relative size of the public acquisitions is generally larger than the private acquisitions, there may be two effects driving these results; the relative size effect and the target status effect. We further analyze the two effects by selecting matched-sample acquisitions by their relative sizes, and rerun the abnormal returns analysis. The results are shown in Table 5(c). The table reveals that public acquisitions yield greater returns compared to the private acquisitions for all sub-windows. Therefore, we conclude that our results indicate the independent existence of both the relative size and target status effects.

Insert Table 5(c)

\subsection{Regression Analysis}

Our analyses in the previous sections reveal the existence of several factors that influence the returns to the acquiring firms; these include method of payment, relative size and target status. In order to complement the univariate analyses, this section presents our results on multivariate regression as an alternative test if those factors are indeed significant in explaining the abnormal returns of the acquiring firms. In addition, the multivariate analysis allows interaction between variables. The acquiring firm cumulative abnormal return over the announcement days, CAR(-1,1) is used as the dependent variable. The explanatory variables include three dummies (for cash settlement, multiple bidders and public targets), three interaction variables and the log of deal value relative size. The data for the OLS regression consists of all-cash and all-share methods of payment only, excluding the mixed offer sample, hence the sample size is reduced from 139 to 125 .

The regression equation is as follows:

CAR(-1,1) $=\alpha_{0}+\beta_{1}($ CashDum $)+\beta_{2}($ MultDum $)+\beta_{3}$ LnRS $+\beta_{4}($ PubDum $)+\beta_{5}$ LnRS $*$ CashDum + $\beta_{6}$ LnRS*PubDum $+\beta_{7}$ CashDum*PubDum $+\varepsilon$

where,

CashDum = cash settlement dummy, where CashDum $=1$ if the acquirer uses cash settlement and 0 otherwise,

MultDum $=$ multiple acquisitions dummy, where MultDum $=1$ if acquirer have multiple acquisitions and 0 otherwise,

$L n R S=$ natural $\log$ of relative size. The relative size is measured by the deal value divided by the size of the acquirer.

PubDum = public acquisition dummy, where $=1$ for public acquisition and 0 otherwise, and

LnRS*CashDum, LnRS*PubDum and CashDum*PubDum are interaction variables.

We run three regressions: First, using all the data, then using the subsample data on private and public acquisitions, respectively. The results are presented in Table 6 . The $F$-statistic confirms the overall significance of the regressions, while the adjusted $R$-squared ranges from $11.49 \%$ to $24.85 \%$. The positive intercept for all three regressions confirms that, on average, acquiring firms gain during the 3-days surrounding the announcement period regardless of the target status. The estimates of the coefficients confirm the influence of methods of payment, relative deal size and the target status to acquirers' gains. The coefficient for cash payment is positive for both private and public acquisitions suggesting the overall preference for cash settlement regardless of the target status. The results also show that the coefficient for the relative deal size is significantly positive, which means that the larger the relative deal size the greater is the impact to the acquirer's wealth. This is consistent with the size effect of acquisition where the larger the acquired value compared to the acquirer, the larger would be the value to be added to the acquiring 
firm. The interaction variable representing relative size and cash payment has a positive impact on acquirer's excess returns, suggesting that the influence of cash settlement remains positive after controlling for relative size. Overall, the regression results concur with our univariate analysis.

\section{Insert Table 6}

\section{Conclusion}

In this study, we examine stock market reactions to the acquiring firms in corporate acquisition announcements in Malaysia for the period 2000 to 2005. We use the market model with Scholes-Williams (1977) adjustments for thin trading to obtain the abnormal returns. Our evidence suggests that acquiring firms obtain statistically significant positive abnormal returns on the announcement day (day 0 ) and around the announcement period (days -1 to +1 ). This is consistent with the findings of the previous studies in the Malaysian market, notably Isa and Lim (1993) and Mat-Nor (1993).

Previous studies on the target status reveal that acquiring firms obtain a significant premium when acquiring private (unlisted), as opposed to public (listed) targets. Previous literature proposes that this may be explained by the liquidity hypothesis and managerial motive hypothesis. Our evidence shows the opposite in the Malaysian context: acquiring firms that acquire public targets obtain greater abnormal returns than those that acquire private targets. Our results are consistent with the bargaining power hypothesis. The management of the private target has greater bargaining power by virtue of the firm being closely held by a fewer number of shareholders.

Further analysis on the relative size of the deal value confirms that size does matter. We find that for both private and public targets, acquisitions with large relative size outperform the small relative size in terms of providing abnormal returns to acquirers. This finding is consistent with Asquith, Burner and Mullins (1983), Jensen and Ruback (1983) and Fuller et al. (2002) who find that acquirer abnormal returns increase with the relative size of target to acquiring firm. Our matched-pair sample test reveals that public acquisitions provide greater abnormal returns to acquirers than private acquisitions. Hence, there exists the target status effect beyond the relative size.

Abnormal returns to the acquiring firms are also found to be influenced by the methods of payment of the acquisition, either cash or share settlement. Our evidence shows a clear preference of the market for cash offers as opposed to share offers. Cash offers generate a substantial premium over share offers for acquiring firms. We argue that this can be explained by the signaling hypothesis in that acquirers' managers will use cash offers if they believe their shares are undervalued. The evidence that acquiring firms' share prices increase when cash offers are proposed is consistent with this hypothesis. We also find that both the method of payment effect and the targets' status effect are present in our sample; both effects seem to exist independently.

\section{References}

Agrawal, R. K. and Samwick, A. A. (2003). Why do managers diversify their firms? Agency reconsidered. Journal of Finance, 58(1), 71-118.

Amihud, Y. Lev, B. and Travlos, N. G. (1990). Corporate control and the choice of investment financing: The case of corporate acquisitions. Journal of Finance, 45(2), 603-616.

Andrade, G., Mitchell, M. and Stafford, E. (2001). New evidence and perspective on mergers. Journal of Economic Perspective, 15(2), 103-120.

Ang, J. and Kohers, N. (2001). The take-over market for privately held companies: The US experience. Cambridge Journal of Economics, 23(26), 723-747.

Asquith, P. and Kim, E. H. (1982). The impact of merger bids on the participating firms' security holders. Journal of Finance, 37(5), 1209-1228.

Asquith, P., Burner, R. F. and Mullins, Jr.D. (1983). The gains to bidding firms from merger. Journal of Financial Economics, 11(1), 121-139.

Bradley, M., Desai, A. and Kim, E. H. (1983). The rationale behind interfirm tender offers: information or synergy? Journal of Financial Economics, 11(1-4), 183-206.

Chang, S. Y. (1998). Takeovers of privately held targets, methods of payment, and bidder returns. Journal of Finance, 53(2), 773-784.

Cheung, Y. L. and Shum, C. K. (1993). Corporate takeover and shareholders' wealth in Hong Kong. British Accounting Review, 25(3), 213-226.

Conn, R. L., Cosh, A., Guest, P. M. and Hughes, A. (2005). The impact on UK acquirers of domestic, cross-border, public and private acquisitions. Journal of Business Finance and Accounting, 32(5\&6), 815-870. 
Da Silva Rosa, R., Izan, H.Y., Steinback, A. and Walter, T. (2000). The method of payment decision in Australia takeovers: An investigation of causes and effects. Australia Journal of Management, 25(1), 76-94.

Draper, P. and Paudyal, K. (1999). Corporate takeovers: Mode of payment, returns and trading activity. Journal of Business Finance and Accounting, 26(5\&6), 521-558.

Draper, P. and Paudyal, K. (2006). Acquisitions: Private versus public. European Financial Management, 12(1), 57-80.

Eckbo, B. E., Maksimovic, Y. and Williams, J. (1990). Consistent estimation of cross-sectional models in event studies. Review of Financial Studies, 3(3), 343-365.

Faccio, M. and Masulis, R. W. (2005). The choice of payment method in European mergers and acquisitions. Journal of Finance, 60(3), 1345-1388.

Faccio, M., McConnell, J. J. and Stolin, D. (2006). Returns to acquirers of listed and unlisted targets. Journal of Financial and Quantitative Analysis, 4(1), 197-220.

Fuller, K., Netter, J. and Stegemoller, M. (2002). What do returns to acquiring firms tell us? Evidence from firms that make many acquisitions. Journal of Finance, 57(4), 1763-1793.

Healy, P.M., Palepu, K.G. and Ruback, R.S. (1992). Does corporate performance improve after mergers? Journal of Financial Economics, 31(20, 135-175.

Isa, Mansor. and Lim, L. L. (1993). Share price behavior around acquisition announcement in Malaysia. Capital Market Review, 1(2), 1- 23.

Isa, Mansor. (1994). The effects of acquisition announcement and method of payment on shareholder returns in the Malaysian stock market. Security Industry Review, 20(1), 20-31.

Ismail, Ahmad. (2008). Which acquirers gain more, single or multiple? Recent evidence from the USA market. Global Finance Journal, 19(1), 72-84.

Jensen, M. C. and Ruback, R. S. (1983). The market for corporate control: The scientific evidence. Journal of Financial Economics, 11(1-4), 5-50.

Koh, Francis. and Lee, S. H. (1988). Risks and returns of acquiring and acquired firms in Singapore: An empirical analysis. Asia Pacific Journal of Management, 5(3), 157-183.

Leland, H. and Pyle, D. (1977). Informational asymmetries, financial structure, and financial intermediation. Journal of Finance, 32(2), 371-387.

Martynova, M. and Renneboog, L. (2006). The performance of the European market for corporate control: Evidence from $5^{\text {th }}$ takeover wave. ECGI-Finance Working Paper No. 135/2006. Tilburg University, the Netherlands

Martynova, M. and Renneboog, L. (2008). A century of corporate takeovers: What have we learned and where do we stand? Journal of Banking and Finance, 32(10), 2148-2177.

Mat-Nor, Fauzias. (1993). The effects of acquisition announcement on the security prices of bidding and target firms: The Malaysian experience. Irish Business and Administrative Research, 14(2), 114 -126.

Moeller, S. B., Schlingemann, F. P. and Stulz, R. M. (2004). Firm size and the gains from acquisitions. Journal of Financial Economic, 73(2), 210-228.

Moeller, S. B., Schlingemann, F. P. and Stulz, R.M. (2005). Wealth destruction on a massive scale? A study of acquiring-firms returns in the recent merger wave. Journal of Finance, 60(2), 757-782.

Myers, S. C. and Majluf, N. J. (1984). Corporate financing and investment decisions when firms have information that investors do not have. Journal of Financial Economics, 13(2), 187-221.

Rahman, R. A. and Limmack, R. J. (2004). Corporate acquisitions and the operating performance of Malaysian companies. Journal of Business Finance and Accounting, 31(3-4), 359-401.

Scholes, M. and William, J. T. (1977). Estimating betas from nonsynchronous data. Journal of Financial Economics, 5(3), 309-327.

Travlos, N. (1987). Corporate takeover bids, methods of payment, and bidding firms' stock returns. Journal of Finance, 42(4), 943-963.

Travlos, N. and Papaionnou, G. (1991). Corporate acquisitions: Method of payment effects, capital structure effects, and biddings firms' stock returns. Quarterly Journal of Business and Economics, 30(4), 3-22. 
Wansley, J. W, Lane, W. R. and Yang, H. C. (1987). Gains to bidder firms in cash and securities transactions. Financial Review, 22(4), 403-414.

Table 1(a). Sample distribution by year and size of acquirers and target value for private acquisitions

\begin{tabular}{llcccc}
\hline & & \multicolumn{2}{c}{ Acquiring firms (N=107) } & \multicolumn{2}{c}{ Target value (N=107) } \\
\cline { 3 - 6 } Year & $\mathrm{N}$ & Mean Size (RM'000) & Median Size (RM'000) & Mean Size (RM'000) & Median Size (RM'000) \\
\hline 2000 & 21 & 880,926 & 232,100 & 78,954 & 35,396 \\
2001 & 14 & 963,374 & 306.940 & 65,435 & 47,366 \\
2002 & 34 & $1,375,940$ & 274,867 & 57,412 & 32,350 \\
2003 & 24 & 508,545 & 253,932 & 90,213 & 35,877 \\
2004 & 14 & 361,707 & 183,635 & 61,800 & 23,000 \\
\hline Average & & 888,436 & 250,000 & 70,873 & 35,396 \\
\hline
\end{tabular}

Note: During all the years the exchange rate is fixed at RM3.80 $=$ USD1.00.

Table 1(b). Sample distribution by year and size of acquirers and target value for public acquisitions

\begin{tabular}{lccccc}
\hline & & \multicolumn{2}{c}{ Acquiring firms (N=32) } & \multicolumn{2}{c}{ Target value (N=32) } \\
\cline { 3 - 6 } Year & $\mathrm{N}$ & Mean Size (RM'000) & Median Size (RM'000) & Mean Size (RM'000) & Median Size (RM'000) \\
\hline 2000 & 6 & $2,289,211$ & $2,202,524$ & 536,384 & 502,871 \\
2001 & 5 & 885,927 & 404,790 & 466,377 & 535,893 \\
2002 & 6 & $1,014,333$ & 703,603 & 326,049 & 322,026 \\
2003 & 9 & 549,061 & 479,427 & 217,948 & 213,616 \\
2004 & 6 & 991,626 & 745,201 & 282,484 & 278,481 \\
\hline Average & $1,098,194$ & 668,899 & 348,841 & 305,088 \\
\hline
\end{tabular}

Note: During all the years the exchange rate is fixed at RM3.80 $=$ USD1.00.

Table 2(a). Abnormal returns analysis for the entire sample of acquiring firms around the acquisition announcement day.

\begin{tabular}{lccc}
\hline Day & AR (\%) & $\boldsymbol{t}$-statistic & CAR (\%) \\
\hline-30 & 0.1529 & 0.8460 & 0.1529 \\
-20 & 0.1854 & 0.5083 & 0.6006 \\
-10 & -0.2042 & -1.1844 & 0.4480 \\
& & & \\
-5 & -0.1074 & -0.3464 & 0.8772 \\
-4 & 0.0603 & 0.6059 & 0.9375 \\
-3 & 0.0597 & 0.6188 & 0.9972 \\
-2 & 0.0372 & 0.0685 & 1.0344 \\
-1 & -0.0317 & -0.2921 & 1.0027 \\
& & & \\
$\mathbf{0}$ & & & $\mathbf{2 . 0 3 6 2}$ \\
& $\mathbf{1 . 0 3 3 5 * * *}$ & $\mathbf{5 . 4 7 0 7}$ & \\
1 & & & 2.5166 \\
2 & $0.4804 * *$ & 1.9619 & 2.5985 \\
3 & 0.0819 & 0.1227 & 2.5019 \\
4 & -0.0966 & -0.4636 & 2.1537 \\
5 & -0.3482 & -1.0132 & 1.8318 \\
10 & $-0.3219 *$ & -1.6842 & 1.3852 \\
20 & & & 2.69329 \\
\hline
\end{tabular}

Note: Returns are in percentage. $\mathrm{H}_{0}$ : mean daily abnormal returns $\mathrm{AR}_{T}=0$.

***, ${ }^{* *}$ and $*$ indicate significance at the $1 \%$ level, $5 \%$ level and $10 \%$ level. 
Table 2(b). Cumulative abnormal returns (CAR) for acquiring firms: all sample

\begin{tabular}{|c|c|c|}
\hline \multirow[b]{2}{*}{$\begin{array}{l}\text { Holding Returns } \\
\text { CAR Range }\end{array}$} & \multicolumn{2}{|c|}{ Acquiring Firms (N=139) } \\
\hline & CAR (\%) & $t$-statistic \\
\hline Day -30 to Day 2 & 1.0344 & 0.6420 \\
\hline Day -1 to Day 1 & $1.4822 * *$ & 3.3597 \\
\hline Day 2 to Day 30 & 0.1263 & 0.8886 \\
\hline Day -5 to Day 5 & $0.8472 *$ & 1.8788 \\
\hline Day -20 to Day 20 & 1.5784 & 1.2239 \\
\hline
\end{tabular}

Note: Returns are in percentage. $\mathrm{H}_{0}$ : cumulative mean daily abnormal returns in the interval, $\mathrm{CAR}_{T 1, T 2}=0$.

$* * *, * *$ and $*$ indicate significance at the $1 \%$ level, $5 \%$ level and $10 \%$ level, respectively.

Table 3. Cumulative abnormal returns (CAR) of acquiring firm by target status: all sample

\begin{tabular}{lcccc}
\hline & & & \multicolumn{2}{c}{ Public Acquisitions (N=32) } \\
\cline { 2 - 5 } Holding Returns & Private Acquisitions & $(\mathbf{N}=\mathbf{1 0 7})$ & \\
CAR Range & CAR (\%) & t-statistic & CAR (\%) & t-statistic \\
\hline Day -30 to Day -2 & -0.5649 & 0.4761 & 2.9090 & 0.1045 \\
Day -1 to Day 1 & $1.2442^{* * *}$ & 2.8426 & $2.2025^{* *}$ & 2.0413 \\
Day 2 to Day 30 & -0.1801 & 0.9404 & -0.5797 & 1.0233 \\
Day -5 to Day 5 & $-0.0718^{*}$ & 1.6978 & 2.5501 & 1.3170 \\
Day -30 to Day 30 & 0.4992 & 0.9621 & 4.5318 & 1.0254 \\
\hline
\end{tabular}

Note: Returns are in percentages. Public acquisitions refer to acquiring a listed target and private acquisitions refer to acquiring an unlisted target. H0: cumulative mean daily abnormal returns in the interval, $\mathrm{CAR} \mathrm{T} 1, \mathrm{~T} 2=0$.

$* * *, * *$ and $*$ indicate significance at the $1 \%$ level, $5 \%$ level and $10 \%$ level, respectively.

Table 4. Cumulative abnormal returns (CAR) of acquiring firm by method of payment and target status.

\begin{tabular}{|c|c|c|c|c|c|c|}
\hline \multicolumn{7}{|c|}{ Panel A: Cash Acquisitions } \\
\hline \multirow{2}{*}{$\begin{array}{l}\text { Holding Returns } \\
\text { CAR Range }\end{array}$} & \multicolumn{2}{|c|}{ Private Acquisition } & \multicolumn{2}{|c|}{ Public Acquisition } & \multicolumn{2}{|c|}{$\underline{\text { All Acquisitions }}$} \\
\hline & CAR (\%) & $t$-statistic & CAR (\%) & $t$-statistic & CAR (\%) & $t$-statistic \\
\hline Day -30 to Day -2 & 0.2014 & 0.5866 & 4.8274 & 0.8025 & 1.5262 & 0.7020 \\
\hline Day -1 to Day 1 & $1.0237 * *$ & 2.3344 & $2.6987 * *$ & 2.6255 & $1.4252 * * *$ & 3.2171 \\
\hline Day +2 to Day 30 & -0.3379 & 0.9549 & 0.2655 & 0.9189 & -0.1014 & 0.8897 \\
\hline Day -5 to Day 5 & -0.2724 & 1.4990 & 4.8201 & 1.5158 & $0.8425^{*}$ & 1.8028 \\
\hline Day -30 to Day 30 & 0.8872 & 0.9301 & 7.7911 & 1.0230 & 2.8500 & 1.0581 \\
\hline \multicolumn{7}{|c|}{ Panel B: Share Acquisitions } \\
\hline Day -30 to Day -2 & -6.9019 & -0.4703 & 2.3282 & 0.7252 & -2.4741 & 0.3633 \\
\hline Day -1 to Day 1 & 1.9813 & 1.1474 & 0.7801 & 0.5119 & 1.8675 & 1.2137 \\
\hline Day +2 to Day 30 & -0.5743 & 0.7530 & -0.0051 & -0.8823 & 0.0903 & 0.8298 \\
\hline Day -5 to Day 5 & -0.2886 & 0.9079 & -0.0795 & 0.6438 & 0.1062 & 0.8953 \\
\hline Day -30 to Day 30 & -5.4949 & -0.6629 & 3.1032 & 0.7959 & -0.5163 & 0.5801 \\
\hline
\end{tabular}

Note: Returns are in percentage. $\mathrm{H}_{0}$ : cumulative mean daily abnormal returns in the interval, $\mathrm{CAR}_{T 1, T 2}=0$.

$* * *, * *$ and $*$ indicate significance at the $1 \%$ level, $5 \%$ level and $10 \%$ level, respectively. 
Table 5(a). Cumulative abnormal returns (CAR) of acquiring firms by relative size (RS) of the acquisition value for private target

\begin{tabular}{lcccc}
\hline & \multicolumn{2}{c}{ Small RS (N=54) } & \multicolumn{2}{c}{ Large RS (N=53) } \\
\cline { 2 - 5 } Holding Returns & \multicolumn{1}{c}{ CAR (\%) } & $\boldsymbol{t}$-statistic & CAR & $\boldsymbol{t}$-statistic \\
\hline CAR Range & & & & \\
Day -30 to Day 2 & -0.3045 & 0.6486 & 0.0856 & 0.7825 \\
Day -1 to Day 1 & $0.6713^{*}$ & 1.7871 & $1.4326^{* * *}$ & 2.9355 \\
Day 2 to Day 30 & 0.5389 & 0.9563 & 0.6268 & 0.9337 \\
Day -5 to Day 5 & 0.5066 & 1.2197 & -0.6886 & 1.8184 \\
Day -30 to Day 30 & 0.9057 & 0.8899 & 2.1450 & 1.0627 \\
\hline
\end{tabular}

Note: Returns are in percentage. $\mathrm{H}_{0}$ : cumulative mean daily abnormal returns in the interval, $\mathrm{CAR}_{T 1, T 2}=0$. $* * *, * *$ and $*$ indicate significance at the $1 \%$ level, $5 \%$ level and $10 \%$ level, respectively.

Table 5(b). Cumulative abnormal returns (CAR) of acquiring firms by relative size (RS) of the acquisition value for public target

\begin{tabular}{|c|c|c|c|c|}
\hline \multirow{2}{*}{$\begin{array}{l}\text { Holding Returns } \\
\text { CAR Range }\end{array}$} & \multicolumn{2}{|c|}{ Small RS $(N=16)$} & \multicolumn{2}{|c|}{ Large RS (N=16) } \\
\hline & CAR (\%) & $t$-statistic & CAR (\%) & $t$-statistic \\
\hline Day -30 to Day 2 & 4.1402 & 1.0077 & 6.4249 & 0.9600 \\
\hline Day -1 to Day 1 & 2.0446 & 1.6296 & $3.3194^{* *}$ & 2.1187 \\
\hline Day 2 to Day 30 & 2.0916 & 1.1441 & 4.4430 & 1.1606 \\
\hline Day -5 to Day 5 & 3.0978 & 1.1073 & 6.5946 & 1.3987 \\
\hline Day -30 to Day 30 & 8.2764 & 1.1116 & 14.1872 & 1.1398 \\
\hline
\end{tabular}

Note: Returns are in percentage. $\mathrm{H}_{0}$ : cumulative mean daily abnormal returns in the interval, $\mathrm{CAR}_{T l, T 2}=0$. $* * *, * *$ and $*$ indicate significance at the $1 \%$ level, $5 \%$ level and $10 \%$ level, respectively.

Table 5(c). Cumulative abnormal returns (CAR) of acquiring firm by target status: matched sample (by relative size)

\begin{tabular}{|c|c|c|c|c|}
\hline Holding Returns & \multicolumn{2}{|c|}{ Private Target $(\mathrm{N}=\mathbf{2 7})$} & \multicolumn{2}{|c|}{ Public Target $(\mathrm{N}=27)$} \\
\hline CAR Range & CAR (\%) & $t$-statistic & CAR (\%) & t-statistic \\
\hline Day -30 to Day 2 & -0.1597 & -0.7392 & 5.4520 & 0.9642 \\
\hline Day -1 to Day 1 & $1.6707^{*}$ & 1.6785 & $2.6151 * * *$ & 2.7799 \\
\hline Day 2 to Day 30 & 0.2006 & 0.8097 & 0.5316 & 1.1365 \\
\hline Day -5 to Day 5 & 2.1125 & 1.1133 & $4.9989^{*}$ & 1.7291 \\
\hline Day -30 to Day 30 & 1.7115 & 0.8426 & 8.5987 & 1.1984 \\
\hline
\end{tabular}

Note: Returns are in percentage. $\mathrm{H}_{0}$ : cumulative mean daily abnormal returns in the interval, $\mathrm{CAR}_{T 1, T 2}=0$. $* * *, * *$ and * indicate significance at the $1 \%$ level, $5 \%$ level and $10 \%$ level, respectively.

Table 6. OLS Regression analyses.

\begin{tabular}{|c|c|c|c|}
\hline Independent Variable & All sample & Private acquisition & Public acquisition \\
\hline Constant & $0.0308 * *$ & $0.0303 * *$ & $0.0620^{* *}$ \\
\hline Cash Dummy, $1=$ cash & $0.0525^{* *}$ & $0.0428^{* *}$ & $0.0983 * * *$ \\
\hline Multiple acquisitions dummy, $1=$ multiple acquisitions & -0.0085 & -0.0128 & 0.0172 \\
\hline Log of deal value relative size (RS) & $0.0190 * * *$ & $0.0152 * * *$ & $0.0377 * *$ \\
\hline Public acquisition dummy, $1=$ public & $0.0464 * *$ & & \\
\hline Interaction variable (RS*CashDum) & $0.0013 * * *$ & $0.0011 * * *$ & $0.0017 * * *$ \\
\hline Interaction variable (RS*PubDum) & -0.0004 & & \\
\hline Interaction variable (CashDum*PubDum) & 0.0196 & & \\
\hline$F$-statistic & $6.8565^{* * *}$ & $3.9862 * * *$ & $3.2432 * * *$ \\
\hline Sample size, $\mathrm{N}$ & 125 & 93 & 32 \\
\hline Adjusted $R$-Squared & 0.2485 & 0.1149 & 0.2245 \\
\hline
\end{tabular}

Note: Dependent variable is CAR $(-1,+1)$. The total sample size for the OLS regression consists of all-cash and all-share methods of payment only. 


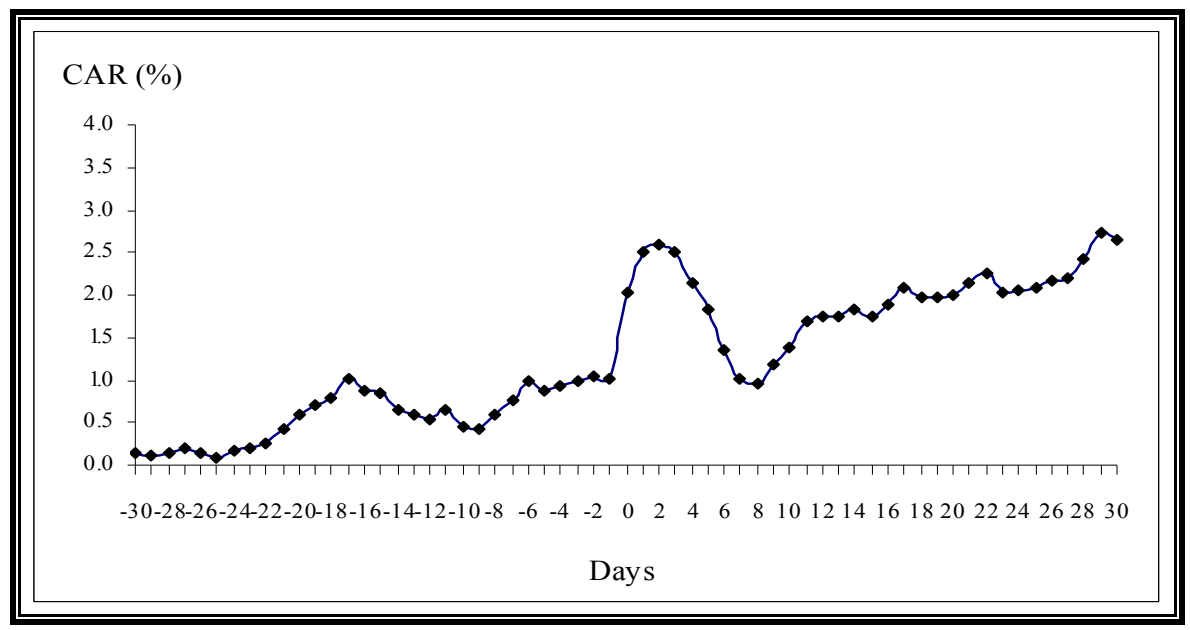

Figure 1. Cumulative Abnormal Returns (CAR) for acquiring firms. 